\title{
The Development of Mobile Augmented Reality-Based Science Learning Media on Earth Layer Materials and Disasters in Class VII Junior High School
}

\author{
Miftahul Farhani Isty ${ }^{* 1)}$, M. Nor ${ }^{2)}$, Muhammad Sahal ${ }^{3)}$ \\ ${ }^{1,2,3)}$ Physics Education,University of Riau \\ e-mail: ${ }^{* 1)}$ miftahulfarhaniisty22@gmail.com \\ mnoer_rs@yahoo.com \\ mhmmdsahal18@gmail.com
}

\begin{abstract}
This research aims to produce products in the form of printed modules and CDs containing augmented reality (AR) applications. The AR application on the CD was transferred to the mobile phone and installed. Augmented reality technology in the form of $3 D$ animation and video appears by scanning markers or images in the module using the AR application camera on the mobile phone. One of the 3D animations shown is an animation of the earth, while one of the videos shown is a video about layers in the Earth's atmosphere. This research method uses research and development $R \& D$ (Research and Development) with the ADDIE model development model. The ADDIE model consists of analysis, design, development, implementation, and evaluation. This research is only up to the development stage. The source of the data used in this research is the assessment score that comes from a questionnaire in the form of a checklist filled out by an expert validator. The data obtained showed that the material validation score was 3.48 (high category) and the media validation score was 3.51 (very high category). The results of this research indicate that the mobile augmented reality-based science learning media on the Earth layer and disaster material has been valid in terms of material and media, so it is suitable to be used as a learning media for the Earth layer and disaster in class VII junior high school.
\end{abstract}

Keywords : learning media, augmented reality, earth layers and disasters. 


\title{
Pengembangan Media Pembelajaran IPA Berbasis Mobile Augmented Reality pada Materi Lapisan Bumi dan Bencana di Kelas VII SMP
}

\author{
Miftahul Farhani Isty ${ }^{* 1)}$, M. Nor ${ }^{2)}$, Muhammad Sahal ${ }^{3)}$ \\ ${ }^{1,2,3)}$ Pendidikan Fisika, Universitas Riau
}

\begin{abstract}
Abstrak
Penelitian ini bertujuan untuk menghasilkan produk dalam bentuk modul cetak dan CD berisi aplikasi augmented reality (AR). Aplikasi AR pada $\mathrm{CD}$ dipindahkan ke mobile phone dan diinstall. Teknologi augmented reality berupa animasi 3D dan video muncul dengan cara menscan marker atau gambar di dalam modul dengan menggunakan kamera aplikasi AR di dalam mobile phone. Salah satu animasi 3D yang ditampilkan yakni animasi bumi sedangkan salah satu video yang ditampilkan yakni video tentang lapisan pada atmosfer. Metode penelitian ini menggunakan penelitian dan pengembangan R\&D (research and development) dengan model pengembangan model ADDIE. Model ADDIE terdiri dari analisis, desain, pengembangan, implementasi dan evaluasi. Penelitian ini hanya sampai tahap pengembangan. Sumber data yang digunakan dalam penelitian ini adalah skor penilaian yang berasal dari kuesioner berbentuk checklist yang diisi oleh validator ahli. Data yang diperoleh menunjukkan bahwa skor validasi materi sebesar 3,48 (kategori tinggi) dan skor validasi media sebesar 3,51 (kategori sangat tinggi). Sebagai kesimpulan, hasil penelitian ini menunjukkan bahwa media pembelajaran fisika berbasis mobile augmented reality pada materi lapisan bumi dan bencana di kelas VII SMP telah valid dari segi materi dan media sehingga layak dilanjutkan ke penelitian selanjutnya yakni tahap implementasi produk dengan menguji cobakan media ini ke lapangan.
\end{abstract}

Kata Kunci : media pembelajaran, augmented reality, lapisan bumi dan bencana.

\section{Pendahuluan}

Ada beberapa materi yang sulit dijelaskan hanya dengan metode ceramah. Salah satunya yakni materi lapisan bumi dan bencana. Oleh karena itu diperlukan bantuan perangkat TI (Teknologi Informasi) untuk memudahkan pemahaman dari materi tersebut. Perkembangan teknologi informasi saat ini tumbuh dengan sangat pesat dari hari kehari, termasuk dalam bidang mobile phone. Penggunaan mobile phone semakin bertambah, apalagi karena harganya yang semakin terjangkau. Di Indonesia, mobile phone dipakai oleh banyak kalangan, baik anak-anak, remaja dan orang dewasa. Sayangnya, mobile phone seringkali tidak dimanfaatkan dengan baik. Padahal mobile phone dapat dimanfaat-kan dalam dunia pendidikan sebagai media pembelajaran.

Guru merupakan fasilitator yang memiliki tanggung jawab dalam proses pembelajaran. Efektif tidaknya proses pembelajaran siswa di sekolah tidak hanya berasal dari potensi diri siswa, melainkan juga lingkungan proses pembelajaran. Guru profesional dituntut untuk bisa menentukan metode dan media pembelajaran yang tepat untuk digunakan dalam proses pembelajaran (Ghiffary, 2019).

Pembelajaran IPA di kelas VII Sekolah Menengah Pertama (SMP) materi lapisan bumi dan bencana masih diajarkan guru dengan metode ceramah layaknya pembelajaran konvensional. Padahal materi ini merupakan materi abstrak yang sulit siswa pahami. Dalam penelitian Sari et al. (2018) diketahui juga bahwa siswa umumnya masih malas membaca atau memahami materi lapisan bumi dan bencana.

Depdiknas dalam Nurhasanah (2018) meyatakan lapisan Bumi dan bencana adalah materi baru bagi siswa SMP sesuai Permendikbud nomor 21 tahun 2016, dimana penerapannya baru dilaksanakan pada tahun ajaran 2016/2017. Materi yang tersaji pada bukubuku pengangan siswa cenderung abstrak dan terbatas, sehingga menyulitkan tercapainya tujuan pembelajaran. Buku cetak sekolah yang membahas materi lapisan bumi dan bencana memiliki kelemahan hanya mampu menunjukkan materi dalam gambar dua dimensi saja. Padahal akan lebih menarik jika dimodifikasi, 
sehingga dapat memunculkan animasi 3D dan video. Karimatussalamah (2018) menyatakan siswa menginginkan pembelajaran yang menarik dan berkesan serta penggunaan bahan ajar yang menarik yang mampu merangsang motivasi belajar. Guru sebaiknya mampu berinovasi agar pelajaran materi lapisan bumi dan bencana ini dapat diajarkan dengan baik dan dipahami oleh seluruh siswa/siswi. Salah satu langkah yang bisa diambil yakni dengan menggunakan media pembelajaran yang tepat.

Media sering diartikan sebagai alat untuk memudahkan pemberian informasi (pesan) antara pemberi dengan penerima pesan. Menurut Associatin for Education and Communication Technology/AECT dalam Ghiffary (2019) media merupakan segala bentuk yang tujuannya memudahkan proses penyajian informasi. Guru dalam sistem pembelajaran dituntut untuk dapat memilih media pembelajaran yang tepat. Strategi pembelajaran yang tepat dapat meningkatkan pemahaman siswa dalam proses pembelajaran dan menciptakan suasana belajar yang menyenangkan. Putra (2013) dalam kajiannya menyatakan bahwa pemanfaatan media pembelajaran yang diterapkan pada proses pembelajaran dapat meningkatkan minat siswa dalam mengikuti materi yang disampaikan oleh guru.

Salah satu media pembelajaran adalah media cetak dalam bentuk buku teks atau modul. Arsyad dalam Bakri et al. (2018) mengemukakan bahwa media buku teks jika digunakan memiliki kelebihan yakni siswa dapat mengulangi materi dan tidak membuat mata cepat lelah, mengikuti urutan pikiran secara logis, dan maju sesuai dengan kecepatan masing-masing siswa. Sedangkan kelemahannya yakni media cetak sulit menampilkan gerak dalam halamannya, selain itu, jika tidak dirancang dengan baik dapat membuat siswa merasa bosan. Penggunaan buku teks juga membuat kesempatan belajar siswa secara nyata terbatas.

Saputro \& Saputra (2014) menyatakan media pembelajaran selalu berkembang sejalan dengan perkembangan teknologi, baik teknologi cetak, audio visual, komputer hingga teknologi gabungan antara cetak dengan komputer. Sejalan dengan perkembangan teknologi, dapat dibuat sebuah media buku yang didalamnya terdapat augmented reality
(AR). Hal ini mampu meminimalisir kelemahan dari media buku teks ataupun modul seperti yang telah dipaparkan sebelumnya.

Menurut Valino dalam Suryaningsih (2019) augmented reality adalah teknologi yang menggabungkan benda maya dua dimensi atau tiga dimensi kemudian memproyeksikan benda maya tersebut dalam waktu nyata. Menurut Azuma dalam Mustaqim (2016) augmented reality adalah teknologi yang menggabungkan dunia nyata dengan dunia maya, bersifat interaktif menurut waktu nyata, serta berbentuk animasi tiga dimensi. Teknologi augmented reality dalam penggunaannya memerlukan bantuan perangkat lain, misalnya smartphone dan tablet dengan sistem operasi android (Wahyudi, 2014).

Pada zaman milenial ini, hampir semua orang menggunakan mobile phone atau smartphone. Augmented reality yang di hubungkan dengan mobile phone atau smartphone dapat mudah diakses dan dioperasikan oleh banyak pihak, tak hanya guru namun juga siswa. Augmented reality yang dikemas menarik dan mudah digunakan akan menjadi poin plus dalam dunia pembelajaran.

Augmented reality dalam media pembelajaran dapat memberikan siswa sumber belajar baru dalam memahami konsep lapisan bumi dan bencana, mendorong siswa untuk berfikir berdasarkan konsep dan merasakan 3D (tiga dimensi) dan animasi, serta menciptakan suasana belajar yang interaktif dan atraktif. Selain itu, pembelajaran di kelas menjadi lebih menyenangkan (Ivanova \& Georgi, 2011).

Materi lapisan bumi dan bencana yang abstrak dapat dibuat media pembelajarannya yakni modul plus CD yang berisi aplikasi AR, dimana di dalam modul terdapat markermarker berupa gambar yang apabila gambar tersebut discan menggunakan aplikasi AR akan memunculkan teknologi augmented reality. Penggunaan teknologi augmented reality pada materi lapisan bumi dan bencana yang abstrak mampu menghadirkan animasi 3 dimensi yang terlihat real dihadapan siswa/siswi. Selain itu teknologi augmented reality menurut Candra dalam Saputro \& Saputra (2014) dapat dimanfaatkan sebagai perpanjangan informasi dari media promosi cetak ke media promosi berbentuk video menggunakan teknologi AR. Dengan demikian 
siswa menjadi tertarik dan lebih mengerti mengenai materi tersebut.

Penelitian ini bertujuan untuk mengembangkan media pembelajaran fisika berbasis mobile augmented reality yang valid digunakan untuk meningkatkan kemampuan kognitif siswa SMP pada materi lapisan bumi dan bencana.

\section{Metode Penelitian}

Penelitian ini dilaksanakan di Laboratorium Pengembangan Media Pembelajaran Fisika Universitas Riau selama 1 semester yakni pada semester ganjil tahun 2020 . Penelitian ini menggunakan metode R\&D (Research and Development) dan menggunakan model perancangan media pembelajaran (Instructional Design) tipe ADDIE seperti pada Gambar 1.

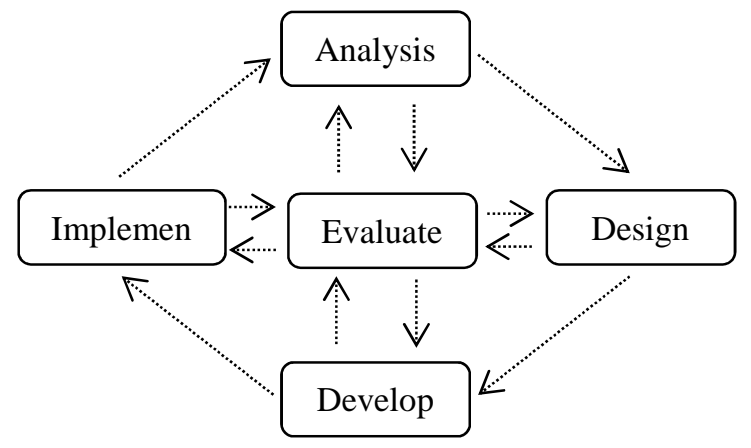

Gambar 1. Model ADDIE (Tegeh et al., 2015).

Pemilihan pendekatan ini didasari oleh tujuan penelitian yakni untuk membuat media pembelajaran fisika berbasis mobile augmented reality pada materi lapisan Bumi dan bencana di kelas VII SMP.

Model ADDIE yang digunakan pada penelitian ini hanya dilakukan sampai tahap pengembangan (development) dengan menghasilkan produk pembelajaran dan melakukan validasi terhadap produk tersebut. Penelitian ini diawali dengan melakukan analisis (analysis) permasalahan yang dihadapi di sekolah dalam proses pembelajaran pada materi lapisan bumi dan bencana. Analisis studi literature dilakukan dengan menelaah beberapa artikel yang berkaitan dengan lapisan bumi dan bencana, sedangkan telaah kurikulum dilakukan sebagai acuan dalam perancangan media yang ingin dikembangkan.

Tahap selanjutnya adalah tahap desain, dilakukan kegiatan perancangan modul yang hendak dibuat, merancang marker, serta merancang video dan animasi 3D yang disesuaikan dengan silabus K13 revisi materi lapisan bumi dan bencana. Tahap berikutnya yakni tahap pengembangan, dilakukan kegiatan mewujudkan desain menjadi kenyataan untuk menghasilkan bentuk akhir dari media pembelajaran fisika berbasis mobile augmented reality melalui revisi berdasarkan masukan para ahli atau pakar.

Menurut Sugiyono (2015) instrumen merupakan alat yang digunakan untuk memperoleh data. Instrumen yang digunakan untuk penelitian ini adalah lembaran validasi berupa kuesioner bentuk checklist $(\sqrt{ })$. Teknik pengumpulan data dilakukan dengan cara pengisian kuesioner bentuk checklist $(\sqrt{ })$ oleh validator ahli materi dan ahli media yakni 3 orang dosen pendidikan fisika FKIP Universitas Riau. Teknik pengumpulan data dilakukan dengan memberikan kuesioner bentuk checklist $(\sqrt{ })$ kepada validator bersama dengan media yang sudah dikembangkan agar bisa dinilai.

Tahapan yang digunakan untuk menentukan validitas produk pembelajaran yang dikembangkan yakni: pertama menentukan kategori dan skor untuk jawaban instrumen validasi yang diisi oleh validator dengan mengunakan skala likert seperti pada Tabel 1.

Tabel 1. Kategori skala likert

\begin{tabular}{ccl}
\hline No & Skor & \multicolumn{1}{c}{ Kategori } \\
\hline 1 & 4 & Sangat Baik \\
2 & 3 & Baik \\
3 & 2 & Tidak Baik \\
4 & 1 & Sangat Tidak Baik
\end{tabular}

Sumber: (Aminrais \& bambang, 2014).

Selanjutnya, dilakukan pencarian rata-rata tiap indikator hasil penilaian validator dan menentukan tingkat kelayakannya. Suatu item penilaian dinyatakan valid apabila semua validator memberikan skor minimal 3. Tingkat kelayakan media pembelajaran berbasis mobile augmented reality ini dilihat menggunakan indeks validitas yang dijabarkan pada Tabel 2 . 
Tabel 2. Kategori validitas

\begin{tabular}{cc}
\hline Indeks Validitas & Kategori \\
\hline $3,50 \leq \mathrm{x} \leq 4,00$ & Sangat Tinggi \\
$3,00 \leq \mathrm{x}<3,50$ & Tinggi \\
$2,00 \leq \mathrm{x}<3,00$ & Rendah \\
$1,00 \leq \mathrm{x}<2,00$ & Sangat Rendah \\
\hline
\end{tabular}

Media pembelajaran dinyatakan valid apabila seluruh itemnya mendapat skor 3 dari validator atau indeks validitas minimal 3,00.

\section{Hasil dan Pembahasan}

Penelitian ini menghasilkan media pembelajaran yakni modul materi lapisan Bumi dan bencana yang dilengkapi dengan $\mathrm{CD}$ berisi aplikasi augmented reality. Berdasarkan tahap analisis didapatkan hasil analisis kebutuhan yakni guru masih menggunakan metode ceramah dalam mengajar materi lapisan bumi dan bencana, guru juga tidak menggunakan media dalam mengajar materi ini. Padahal materi lapisan bumi dan bencana merupakan materi abstrak. Sehingga menyebabkan peserta didik mengaku kesulitan memahami dan kurang berminat dalam belajar materi ini. Pada studi literatur diperoleh dalam penelitian Sari et al. (2018) yakni siswa umumnya masih malas membaca atau memahami materi lapisan bumi dan bencana. Depdiknas dalam Nurhasanah (2018) meyatakan lapisan Bumi dan bencana sebagai materi baru bagi siswa SMP. Materi yang tersaji pada buku-buku pengangan siswa cenderung abstrak dan terbatas sehingga tujuan pembelajaran sulit tercapai. Buku cetak sekolah yang membahas materi lapisan bumi dan bencana memiliki kelemahan hanya mampu menunjukkan materi dalam gambar 2 dimensi saja padahal akan lebih menarik dan memotivasi jika dapat memunculkan animasi 3D dan video. Studi literatur juga dilakukan untuk melihat penelitian-penelitian sejenis mengenai media yang hendak dikembangkan yakni media berbasis augmented reality. Melalui studi literatur, peneliti menemukan banyak sumber mengenai modul berbasis augmented reality yang telah dikembangkan oleh peneliti lain. Sedangkan pada telaah kurikulum, peneliti menyesuaikan media pembelajaran yang dikembangkan dengan kurikulum 2013 revisi.

Tahap desain dari media pembelajaran fisika berbasis mobile augmented reality dirancang dengan menggunakan berbagai aplikasi seperti tertera pada Tabel 3 .

Tabel 3. Aplikasi yang digunakan dalam pembuatan media pembelajaran berbasis AR

\begin{tabular}{ll}
\hline Produk & $\begin{array}{l}\text { Aplikasi yang } \\
\text { digunakan }\end{array}$ \\
\hline Modul & Microsoft word \\
Marker & photoshop \\
Video pembelajaran & Filmora \\
Animasi 3D & Blender \\
\hline
\end{tabular}

Selanjutnya, pada tahap pengembangan, dikembangkan media pembelajaran fisika berbasis mobile augmented reality pada materi lapisan bumi dan bencana di kelas VII SMP. Tampilan sampul modul dapat dilihat pada Gambar 2, sedangkan tampilan isi dapat dilihat pada Gambar 3.

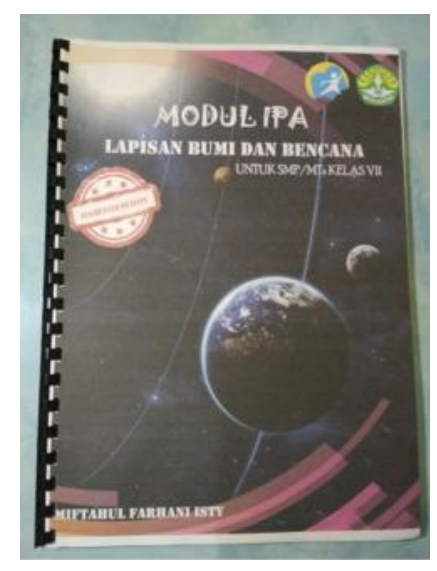

Gambar 2. Sampul modul IPA.

Modul IPA materi lapisan bumi dan bencana ini terdiri dari kata pengantar, Daftar Isi, Kompetensi, Peta Konsep, Materi lapisan bumi dan bencana, Rangkuman, soal-soal beserta kunci jawabannya dan daftar pustaka. Sedangkan CD berisi Aplikasi AR yang dikembangkan dalam format APK dan petunjuk menginstal aplikasi ke mobile phone dalam format Microsoft Word. Tampilan CD dapat dilihat pada Gambar 4. 


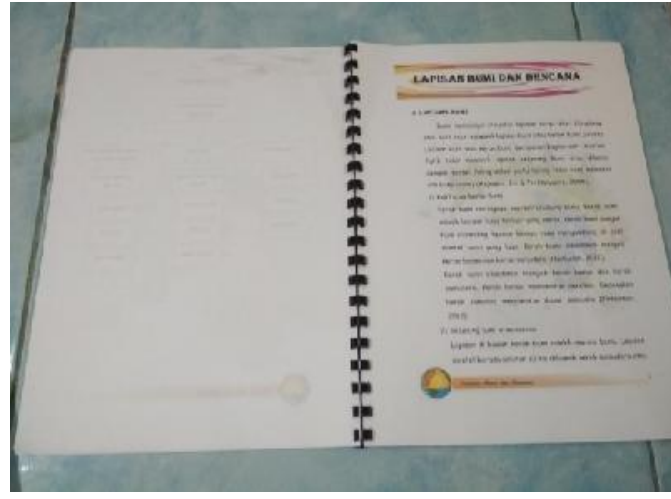

Gambar 3. Isi modul IPA.

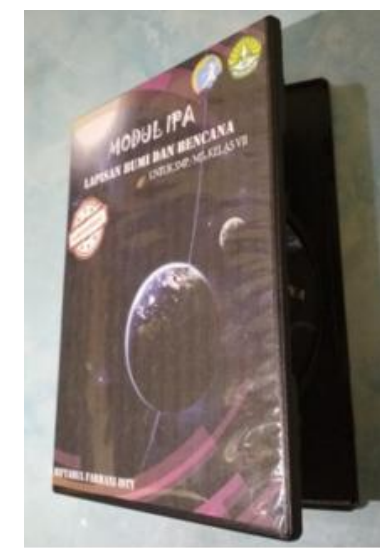

Gambar 4. CD modul IPA Sekolah.

Aplikasi dalam CD dapat diinstal di mobile phone guru maupun siswa dengan ukuran yakni $174 \mathrm{mb}$. Aplikasi mobile augmented reality atau disingkat dengan MAR lapisan bumi dan bencana apabila telah terinstal di mobile phone memiliki Icon seperti Gambar 5.
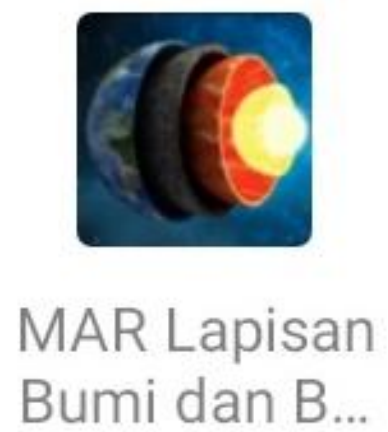

Gambar 5. Icon aplikasi mobile augmented reality lapisan Bumi dan bencana.
Saat aplikasi dibuka, maka aplikasi akan memunculkan kamera. Teknologi augmented reality akan muncul ketika kamera aplikasi AR tersebut diarahkan ke gambar dalam modul. Augmented reality yang muncul yakni berupa video atau animasi 3D seperti yang terlihat Gambar 6 dan Gambar 7.

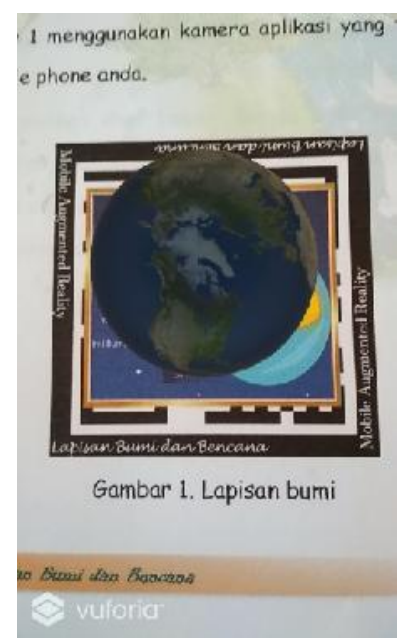

Gambar 6. Teknologi augmented reality berupa animasi 3D.

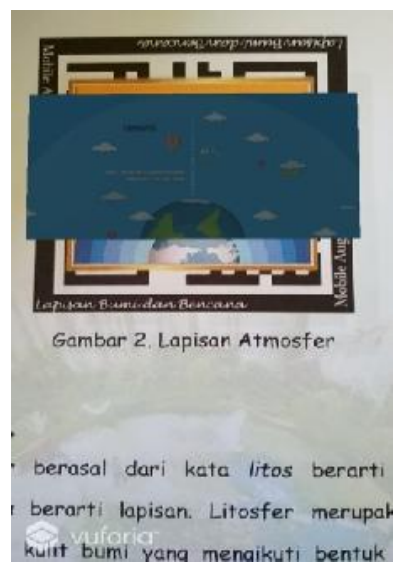

Gambar 7. Teknologi augmented reality berupa video.

Media pembelajaran berbasis mobile augmented reality ini dilakukan validasi untuk melihat tingkat kelayakannya dari segi materi dan media. Dari segi materi dilihat dalam beberapa aspek yakni aspek materi, soal dan bahasa. Sedangkan dari segi media dilihat dalam aspek perangkat lunak dan komunikasi visual. Validasi dilakukan sebanyak 2 kali yakni validasi tahap pertama dan validasi tahap 
kedua. Pada tahap pertama masih terdapat indikator yang harus diubah sesuai saran validator baik dalam segi materi maupun media.

Media pembelajaran berbasis mobile augmented reality dilakukan perbaikan sesuai saran validator hasil validasi tahap pertama. Setelah itu, dilakukan validasi tahap kedua dengan menggunakan angket yang sama serta membawa media yang telah disempurnakan. Hasil validasi tahap kedua diperoleh peningkatan skor baik dari segi materi maupun media. Skor penilaian hasil validasi tahap kedua dari segi materi dapat dilihat pada Tabel 4.

Tabel 4. Rata-rata skor penilaian tiap aspek segi materi

\begin{tabular}{|c|c|c|c|}
\hline No. & Pernyataan & Rata-rata & Kategori \\
\hline \multicolumn{4}{|c|}{ Aspek Materi } \\
\hline 1. & Materi yang disampaikan sesuai dengan KD & 3,67 & ST \\
\hline 2. & Materi yang disampaikan sesuai dengan tujuan pembelajaran & 3,33 & $\mathrm{~T}$ \\
\hline 3. & Materi yang disampaikan actual & 3,00 & $\mathrm{~T}$ \\
\hline 4. & Materi yang disampaikan dalam media lengkap & 3,33 & $\mathrm{~T}$ \\
\hline 5. & Materi disampaikan dengan jelas & 3,67 & ST \\
\hline 6. & Materi disampaikan secara sistematis & 3,67 & ST \\
\hline 7. & Materi yang disampaikan dikemas secara menarik & 3,33 & $\mathrm{~T}$ \\
\hline 8. & Materi yang disajikan mudah dipahami & 3,67 & $\mathrm{ST}$ \\
\hline 9. & Materi sesuai dengan tingkat kemampuan anak & 3,00 & $\mathrm{~T}$ \\
\hline \multirow[t]{2}{*}{10} & Ketepatan penggunaan ilustrasi & 3,67 & ST \\
\hline & Jumlah rata-rata & 3,43 & $\mathrm{~T}$ \\
\hline \multicolumn{4}{|c|}{ Aspek Soal } \\
\hline 11. & Soal dirumuskan dengan jelas & 3,33 & $\mathrm{~T}$ \\
\hline & Soal di dalam media lengkap & 3,33 & $\mathrm{~T}$ \\
\hline 13. & Soal sesuai teori dan konsep & 3,33 & $\mathrm{~T}$ \\
\hline \multirow[t]{2}{*}{14.} & Kunci jawaban sesuai dengan soal & 3,33 & $\mathrm{~T}$ \\
\hline & Jumlah rata-rata & 3,33 & $\mathrm{~T}$ \\
\hline \multicolumn{4}{|c|}{ Aspek Bahasa } \\
\hline 15. & Bahasa yang digunakan komunikatif & 3,67 & ST \\
\hline & Istilah dan pertanyaan yang digunakan tepat dan sesuai & 3,67 & ST \\
\hline & Jumlah rata-rata & 3,67 & ST \\
\hline & Rata-rata skor keseluruhan & 3,48 & $\mathbf{T}$ \\
\hline
\end{tabular}

Ket. T=Tinggi; ST=Sangat Tinggi.

Tabel 4 memperlihatkan nilai tiap-tiap aspek baik aspek materi, soal maupun bahasa. Apek materi memperoleh nilai rata-rata 3,45 dimana menunjukkan bahwa media pembelajaran yang dikembangkan sudah valid dengan ketegoti tinggi. Hal ini karena materi yang terdapat didalam modul sudah sesuai dengan KD dan tujuan pembelajaran. Materi yang disampaikan juga mudah dipahami dan menggunakan ilustrasi yang tepat.

Selanjutnya nilai aspek soal memiliki nilai 3,33 dengan kategori tinggi. Hal ini karena soal pada modul telah sesuai dengan materi, dirumuskan dengan jelas dan disertai kunci jawaban yang mampu dijadikan sebagai media pembelajaran disekolah maupun pembelajaran mandiri bagi anak di rumah.

Aspek bahasa pada media pembelajaran fsisika berbasis mobile augmented reality memperoleh nilai 3,48 dengan kategori tinggi yang artinya media ini baik modul maupun videonya telah valid.

Selanjutnya, dilihat dari segi media, aspek yang dinilai yakni aspek perangkat lunak dan 
aspek komunikasi visual. Skor penilaian hasil dilihat pada Tabel 5 . validas tahap kedua dari segi media dapat

Tabel 5. Rata-rata skor penilaian tiap aspek segi media

\begin{tabular}{|c|c|c|c|}
\hline No. & Pernyataan & Rata-rata & Kategori \\
\hline \multicolumn{4}{|c|}{ Aspek Perangkat Lunak } \\
\hline & File aplikasi dapat diinstal di android & 3,67 & ST \\
\hline 2. & Aplikasi tidak berjalan lambat & 3,67 & ST \\
\hline 3. & Aplikasi tidak berhenti saat dioperasikan & 3,67 & ST \\
\hline 4. & Aplikasi mudah dijalankan untuk mendeteksi marker & 3,00 & $\mathrm{~T}$ \\
\hline 5. & Terdapat petunjuk penggunaan aplikasi & 3,33 & $\mathrm{~T}$ \\
\hline 6. & Pengoperasian sesuai petunjuk & 3,33 & $\mathrm{~T}$ \\
\hline \multirow[t]{2}{*}{7.} & Pengoperasian sederhana & 3,33 & $\mathrm{~T}$ \\
\hline & Jumlah rata-rata & 3,43 & $\mathrm{~T}$ \\
\hline \multicolumn{4}{|c|}{ Aspek Komunikasi Visual } \\
\hline & Cover modul & 3,67 & ST \\
\hline & Pemilihan grafis background & 3,33 & $\mathrm{~T}$ \\
\hline & Ukuran teks dan jenis huruf pada modul & 3,33 & $\mathrm{~T}$ \\
\hline & Warna dan grafis pada modul menarik & 3,67 & ST \\
\hline 12. & Gambar dan marker yang dipilih & 3,67 & ST \\
\hline 13. & Animasi atau video menarik & 3,67 & ST \\
\hline 14. & Animasi dan video sesuai materi & 3,67 & ST \\
\hline & Suara pada video & 3,67 & ST \\
\hline \multirow[t]{3}{*}{16.} & Daftar isi, peta konsep dan rangkuman & 3,67 & ST \\
\hline & Jumlah rata-rata & 3,59 & ST \\
\hline & Rata-rata skor keseluruhan & $\mathbf{3 , 5 1}$ & ST \\
\hline
\end{tabular}

Ket. T=Tinggi; ST=Sangat Tinggi.

Tabel 5 memperlihatkan nilai rata-rata validator pada aspek perangkat lunak dan aspek komunikasi visual. Aspek perangkat lunak memiliki jumlah rata-rata 3,43, dengan kategori Tinggi. Aspek perangkat lunak ini menilai aplikasi AR yang dikembangkan. Hal ini menunjukkan file aplikasi MAR lapisan bumi dan bencana telah valid dengan kategori tinggi. Penggunaan aplikasi ini juga mudah dan mampu beroperasi dengan baik, sedangkan aspek komunikasi visual memiliki jumlah ratarata 3,59 yang berada dikategori sangat tinggi. Hal ini berarti secara aspek komunikasi visual media yang dikembangkan telah valid.

Media pembelajaran fisika berbasis mobile augmented reality materi lapisan bumi dan bencana dirancang untuk membantu siswa dalam memahami konsep lapisan bumi dan bencana yang bersifat abstrak, modul yang dikembangkan dapat menjadi sumber belajar yang menarik. Selain itu juga dapat menjadi media alternatif untuk guru mengajar dengan metode yang berbeda dan lebih menyenangkan. Media ini dapat meningkatkan motivasi peserta didik dalam belajar lapisan Bumi dan bencana.

Hal ini diperkuat dengan teori pendukung oleh Hendriyani et al. (2019) yang menyatakan teknologi augmented reality memiliki kemampuan untuk membuat model 3D apa pun yang mungkin sulit divisualisasikan di dalam kelas, di komputer atau dipikiran siswa. Konten abstrak dalam model visual membantu siswa mendapat pemahaman lebih dalam tentang topik pelajaran yang dipelajari. Serio, Ibáñez, \& Kloos (dalam Hendriyani et al., 2019) menunjukkan hasil penelitiannya bahwa teknologi augmented reality memiliki dampak positif dalam memotivasi siswa Sekolah Menengah Pertama (SMP).

Dünser et al. (2012) menyatakan AR mem-berikan interaktivitas yang menawarkan potensi, baik belajar maupun penilaian dan objek yang terlalu besar atau terlalu kecil dapat 
dihadirkan dalam situasi pembelajaran. Jadi dengan AR bumi yang besar bisa dihadirkan dalam situasi pembelajaran. Dengan menggunakan augmented reality siswa dapat berinteraksi dengan konten digital yang dapat meningkatkan imajinasi, kreativitas dan belajar (Persefoni \& Tsinakos, 2015). Lebih lanjut, Lee (2012) menjelaskan bahwa augmented reality sangat berpotensi dalam menarik, menginspirasi, dan memotivasi siswa, untuk mengeksplorasi dan menjelajahi serta dapat juga melihat berbagai bentuk permukaan dan geometri.

Secara keseluruhan media pembelajaran fisika berbasis mobile augmented reality pada materi lapisan Bumi dan bencana untuk kelas VII Sekolah Menengah Pertama dinyatakan valid sesuai hasil validasi oleh validator baik dari segi materi maupun media, sehingga media ini layak untuk dilakukan penelitian lebih lanjut dengan mengujicobakan produk ke lapangan persekolahan.

Terdapat kelebihan dan kekurangan media pembelajaran fisika berbasis mobile augmented reality materi lapisan bumi dan bencana untuk kelas VII Sekolah Menengah Pertama. Kelebihan media pembelajaran berbasis mobile augmented reality ini yakni aplikasi yang dikembangkan dapat digunakan secara ofline, sehingga tidak membutuhkan kuota internet. Media pembelajaran fisika berbasis mobile augmented reality ini dapat digunakan secara mandiri jadi bisa digunakan saat masa pandemi maupun saat pembelajaran ofline. Media pembelajaran fisika berbasis mobile augmented reality ini mampu menjelaskan materi lapisan bumi dan bencana yang abstrak menjadi konkrit. Kelemahan media pembelajaran berbasis mobile augmented reality ini yakni ukuran apikasi yang lumayan besar yakni $174 \mathrm{MB}$, sehingga dibutuhkan ruang penyimpanan yang cukup banyak. Untuk mengoperasikan media pembelajaran ini mengunakanan mobile phone sehingga guru dan peserta didik harus memiliki mobile phone. Selain itu modul yang dikembangkan tidak bisa diperbanyak dengan memfotokopi hitam putih, karena jika modul difotokopi hitam putih maka gambar atau marker akan lebih sulit terdeteksi dalam aplikasi.

\section{Kesimpulan}

Media pembelajaran fisika berbasis mobile augmented reality pada materi lapisan bumi dan bencana untuk kelas VII Sekolah Menengah Pertama yang dikembangkan telah valid sesuai hasil validasi dari segi materi maupun media dan layak dilakukan penelitian selanjutnya dengan menguji cobakan produk ke lapangan persekolahan.

Berdasarkan hasil penelitian ini direkomendasikan agar bisa melanjutkan penelitian dengan menerapkan media pada uji skala kecil maupun skala besar ke sekolah dalam proses pembelajaran sehingga produk layak diguna-kan disekolah.

\section{Daftar Pustaka}

Aminrais, S. J. \& Bambang, S. (2014). Uji Validitas Konstruk pada Instrumen Ryff's Psychological Well-Being 42 Version dengan Metode Confirmatory Factor Analysis (Cfa). Prosiding Koferensi Ilmiah Tahunan Himpunan Evaluasi Pendidikan Indonesia (HEPI). 18-20. September 2014. HEPI UKD Bali. Bali.

Bakri, F., Ambarwulan, D., \& Muliyati, D. (2018). Pengembangan Buku Pembelajaran yang Dilengkapi Augmented reality pada Pokok Bahasan Gelombang Bunyi dan Optik. Jurnal Ilmiah Penelitian dan Pembelajaran Fisika, 4(2), 46-56.

Dünser, A., Walker, L., Horner, H., \& Bentall, D. (2012). Creating Interactive Physics Education Books with Augmented Reality. Proceedings of the 24th Australian Computer-Human Interaction Conference.

Ghiffary, M. A. (2019). Keefektifan Game Kuis TTS Pintar sebagai Media Pembelajaran Mata Pembelajaran IPA Terpadu di SMP Islam Cahaya Insani Semarang. Skripsi, Fakultas Ilmu Pendidikan Universitas Negeri Semarang.

Hendriyani, Y., Effendi, H., Novaliendry, D., \& Effendi, H. (2019). Augmented reality sebagai Media Pembelajaran Inovatif di Era Revolusi Industri 4.0. Jurnal Teknologi Informasi dan Pendidikan 12(3), 62-67. 
Ivanova, M. \& Ivanov, G. (2011). Enhancement of Learning and Teaching in Computer Graphics Through Marker Augmented reality Technology. International Journal on New Computer Architectures and Their Applications l(1): 176-184.

Karimatussalamah, S. (2018). Pengembangan Modul IPA untuk Materi Mendeskripsikan Struktur Bumi Siswa Kelas V. Skripsi, Fakultas Keguruan dan Ilmu Pendidikan Universitas Nusantara PGRI Kediri.

Lee, K. (2012). Augmented reality in Education and Training. Research Practice Improve Learning, 56(2), 13-21.

Mustaqim, I. (2016). Pemanfaatan Augmented reality sebagai Media Pembelajaran. JPTK FT UNY, 13(2), 174-183.

Nurhasanah, S. (2018). Pengembangan Media Pembelajaran Floods and Ground Water Infiltration Phenomena (FLOGWIP) untuk Meningkatkan Penguasaan Konsep Materi Lapisan Bumi dan Bencana pada Siswa Kelas VII SMP/MTs. Skripsi, Fakultas Keguruan dan Ilmu Pendidikan Universitas Muhammadiah Malang.

Persefoni, K., \& Tsinakos, A. (2015). Use of Augmented reality in terms of creativity in School learning. ICEC'15, September 29, 2015, Trondheim, Norway.

Putra, I. E. (2013). Teknologi Media Pembelajaran Sejarah Melalui Pemanfaatan Multimedia Animasi Interaktif. Jurnal TEKNOIF, 1(2), 20-25.
Saputro, R. E. \& Saputra, D. I. S. (2014). Pengembangan Media Pembelajaran Mengenal Organ Pencernaan Manusia Menggunkan Teknologi Augmented reality. Jurnal Buana Informatika, 6(2), 153-162.

Sari, E. V., Yurnetti, \& Hamdi. (2018). Pengaruh Pemberian Spelling Puzzle dengan Model Problem Bade Learning terhadap Pencapaian Kompetensi Siswa IPA Kelas VII Materi Pemanasan Global dan Lapisan Bumi SMP Negeri 12 Padang. Pillar of Physics Education, 11(3), 9-16.

Sugiyono. (2015). Metode Penelitian Pendidikan; Pendekatan Kuantitatif, Kualitatif dan $R \& D$. Cetakan ke-19. Bandung: Alfabeta.

Suryaningsih, A. (2019). Gagasan Pengembangan Augmented Reality pada Buku Bacaan sebagai Upaya Meningkatkan Minat Baca Siswa (Adaptasi Percepatan Literasi dari Korea Selatan). Jurnal Ide Guru, 4(1), 35-42.

Tegeh, I. M., Jampel, I. N., \& Pudjawan, K. (2015). Pengembangan Buku Ajar Model Penelitian Pengembangan dengan Model ADDIE. Seminar Nasional dan Riset Inovatif 3: 208-216. Nov. 2015.

Wahyudi, A. K. (2014). ARca, Pengembangan Buku Interaktif Berbasis Augmented reality dengan Smartphone Android. JNTETI, 3(2), 96-102. 